\title{
Investigation on Hydration Process and Biocompatibility of Calcium Silicate-Based Experimental Portland Cements
}

\author{
Jiwon Lim*, Jae-Geun Guk*, Bhupendra Singh**; Yun-Chan Hwang***, \\ Sun-Ju Song (iD) $*, \dagger$ and Ho-Sung Kim ${ }^{*} * \neq$ \\ *Department of Materials Science and Engineering, Chonnam National University, Gwang-Ju 61186, Korea \\ ${ }^{* *}$ CSIR-Advanced Materials and Process Research Institute (AMPRI), Hoshangabad Road, Bhopal 462026, India \\ ***Department of Conservative Dentistry, School of Dentistry, Dental Science Research Institute, \\ Chonnam National University, Gwang-Ju 61186, Korea
}

(Received July 2, 2019; Revised July 12, 2019; Accepted July 12, 2019)

\begin{abstract}
In this work, the hydration process and cytotoxicity of lab-synthesized experimental Portland cements (EPCs) were investigated for dental applications. For this purpose, EPCs were prepared using laboratory-synthesized clinker constituents, tricalcium silicate $\left(\mathrm{C}_{3} \mathrm{~S}\right)$, dicalcium silicate $\left(\mathrm{C}_{2} \mathrm{~S}\right)$, and tricalcium aluminate $\left(\mathrm{C}_{3} \mathrm{~A}\right)$. C-A was prepared by the Pechini method, whereas $\mathrm{C}_{3} \mathrm{~S}$ and $\mathrm{C}_{2} \mathrm{~S}$ were synthesized by solid-state reactions. The phase compositions were characterized by X-ray diffraction (XRD) analysis, and the hydration process of the individual constituents and their combinations, with and without the addition of gypsum, was investigated by electrochemical impedance spectroscopy (EIS). Furthermore, four EPC compositions were prepared using the lab-synthesized C-A, $\mathrm{C}_{3} \mathrm{~S}$, and $\mathrm{C}_{2} \mathrm{~S}$, and their hydration processes were examined by EIS, and their cytotoxicity to HPC and HIPC cells were tested by performing an XTT assay. None of the EPCs exhibited any significant cytotoxicity for 7 days, and no significant difference was observed in the cell viabilities of ProRoot MTA and EPCs. The results indicated that all the EPCs are sufficiently biocompatible with human dental pulp cells and can be potential substitutes for commercial dental cements.
\end{abstract}

Key words : Experimental Portland cement, Hydration process, Electrochemical impedance spectroscopy, Cytotoxicity, Dental cement

\section{Introduction}

$\mathbf{I}_{\mathrm{r}}^{\mathrm{n}}$ $\mathrm{n}$ dentistry, a number of synthetic biomaterials are used for the replacement of destroyed or lost structures and for the restoration of disturbed functions of the orofacial organ. ${ }^{1)}$ Dental cements are such a class of biomaterials that are widely used in restorative dentistry.,3) Inorganic phosphates, ${ }^{4)}$ silicate cements, ${ }^{5,6)}$ glass ionomers and their composites, ${ }^{7,8)}$ and resins ${ }^{9)}$ are the major biomaterials that are used as dental cements. Among the various silicate cements, hydraulic calcium (alumino)silicate cement, more commonly known as mineral trioxide aggregate (MTA), is an alternative biomaterial for dentine replacement, pulp capping, pulpotomy, creation of apical barriers in teeth with open apices, and repair of root perforation and resorptive defects as well

\footnotetext{
${ }^{\dagger}$ Corresponding author: Sun-Ju Song

E-mail : song@chonnam.ac.kr

Tel : +82-62-530-1706 Fax : +82-62-530-1699

ORCID

https://orcid.org/0000-0002-5518-1633

Corresponding author: Ho-Sung Kim

E-mail : symmetry@chonnam.ac.kr

Tel : +82-62-530-1707 Fax : +82-62-530-1699

ORCID

https://orcid.org/0000-0001-8329-0354
}

as orthograde or retrograde root canal fillings. ${ }^{10-12)}$ MTA is a clinker-derived Portland cement composed of different phases, including tricalcium silicate, dicalcium silicate, tricalcium aluminate, tetracalcium aluminoferrite, and calcium sulfate. ${ }^{13-15)}$ However, its higher cost, handling difficulty, and longer setting time are the major impediments to its widespread use. ${ }^{12)}$

Calcium silicate-based Portland cement (PC)-type materials have gained popularity in recent years owing to their resemblance to MTA, and various clinical applications such as root perforations, apexification, resorptions, retrograde fillings, pulp capping procedures, and dentine replacement have been recommended for them. ${ }^{16-18)}$ However, the presence of toxic heavy metals in PC is one of the important aspects in the development of PC-based low-cost dental materials. ${ }^{19-21)}$ To formulate a low-cost material based on MTA or Portland cement with a shorter processing time and minimal cytotoxic implications, several compositional manipulations have been made to the existing commercial dental cements. ${ }^{22-27)}$ In an attempt to develop new endodontic cement from pure raw materials, which has the advantages of both MTA and PC at a lower cost, we had prepared an experimental PC and investigated its physical properties and biocompatibility. ${ }^{28,29)}$

The water dynamics and kinetics of the setting process of calcium silicate-based dental cements are complex pro- 
cesses and highly influenced by the composition, especially that of calcium trisilicate. ${ }^{6,12,30)}$ In the present work, to determine the role of individual constituents-tricalcium silicate $\left(\mathrm{C}_{3} \mathrm{~S}\right)$, dicalcium silicate $\left(\mathrm{C}_{2} \mathrm{~S}\right)$, and tricalcium aluminate $\left(\mathrm{C}_{3} \mathrm{~A}\right)$ - in the setting process, we first investigated the hydration process of these constituents. Then, to develop new compositions of PC-based dental cement, we prepared four different compositions of experimental PC (EPC) by mixing pre-formed $\mathrm{C}_{3} \mathrm{~S}, \mathrm{C}_{2} \mathrm{~S}$, and $\mathrm{C}_{3} \mathrm{~A}$, which are the main constituents of $\mathrm{PC},{ }^{12)}$ in different ratios and investigated their physical properties, setting process, and biocompatibility. The results were compared with those of a commercial dental cement, ProRoot MTA, and an experimental cement (EPC) prepared directly from the pure raw materials. ${ }^{29)}$

The cement paste formed during the setting process is composed of a continuously altering interconnected pore network filled with mobile ion-containing water, which makes it electrically conductive, and the changes in its magnitude with time during the setting process was monitored in situ. ${ }^{31,32)}$ Electrochemical impedance spectroscopy (EIS) is one of the major techniques for the in situ monitoring of hydration process of cement-based materials. ${ }^{33-35)}$ In the present study, we performed frequency-dependent impedance spectroscopy for the in situ monitoring of hydration process of various compositions. Furthermore, the cytotoxicity of various compositions was investigated by performing XTT assays, and the results were compared with those of the commercial dental cement, ProRoot MTA.

\section{Experimental Procedure}

\subsection{Synthesis of $C_{2} S, C_{3} S$, and $C_{3} A$}

$\mathrm{C}_{2} \mathrm{~S}$ and $\mathrm{C}_{3} \mathrm{~S}$ were first synthesized by solid-state reactions between pure raw materials; the purity and mixing ratio of the various raw materials used in the study are listed in Table 1. Fig. 1 shows the flow chart of the various steps involved in the synthesis of $\mathrm{C}_{2} \mathrm{~S}$ and $\mathrm{C}_{3} \mathrm{~S}$. Briefly, for each composition, the raw materials were mixed in an appropriate ratio, as mentioned in Table 1, and ball-milled in isopropyl alcohol (IPA) for $24 \mathrm{~h}$. The ball-milled mixture was dried in a hot-air oven at $80^{\circ} \mathrm{C}$ for $24 \mathrm{~h}$. A semi-dried slurry was prepared by moistening the dried powder with $15 \mathrm{wt} \%$ IPA.

Table 1. Purity and Mix Ratio of Various Raw Materials Used for Synthesis of $\mathrm{C}_{2} \mathrm{~S}$, and $\mathrm{C}_{3} \mathrm{~S}$

\begin{tabular}{lcc}
\hline \multirow{2}{*}{$\mathrm{Raw}$ material } & \multicolumn{2}{c}{ Weight $(\mathrm{g})$} \\
\cline { 2 - 3 } & $\mathrm{C}_{2} \mathrm{~S}$ & $\mathrm{C}_{3} \mathrm{~S}$ \\
\hline $\mathrm{CaO}(98 \%)$ & 5.61 & 8.41 \\
$\mathrm{SiO}_{2}(99.9 \%)$ & 3.00 & 3.01 \\
$\mathrm{Al}_{2} \mathrm{O}_{3}(98 \%)$ & - & - \\
$\mathrm{MgO}(98 \%)$ & 0.06 & 0.17 \\
$\mathrm{Na}_{2} \mathrm{CO}_{3}(98 \%)$ & 0.03 & 0.03 \\
$\mathrm{CaF}_{2}(98 \%)$ & - & 0.06 \\
$\mathrm{Bi}_{2} \mathrm{O}_{3}(98 \%)$ & 0.26 & - \\
\hline
\end{tabular}

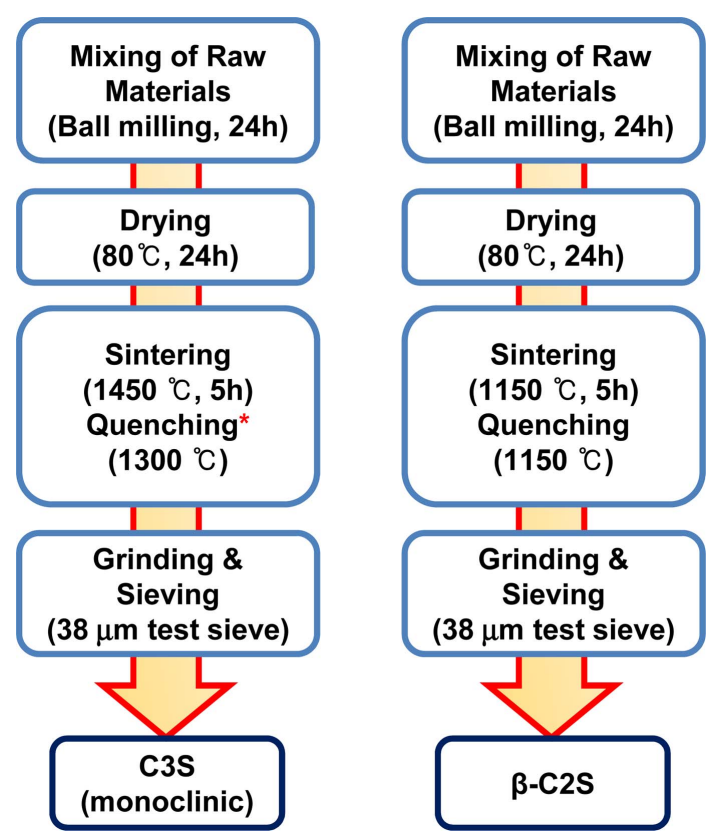

Fig. 1. Flow chart of various steps involved in the synthesis of $\mathrm{C}_{2} \mathrm{~S}$ and $\mathrm{C}_{3} \mathrm{~S}$. In case of $\mathrm{C}_{3} \mathrm{~S}$, quenching was performed after cooling the samples from sintering temperature to $1300^{\circ} \mathrm{C}$.

Spherical balls of $1.5 \mathrm{~cm}$ diameter were formed from the semi-dried slurry and dried in a hot air oven at $80^{\circ} \mathrm{C}$ for 1 day. The dried spheres were sintered in air at different temperatures and then quenched in liquid nitrogen. The heating rate during sintering was fixed as $3^{\circ} \mathrm{C} / \mathrm{min}$. The clinker obtained after quenching was fully ground and sieved using $38 \mu \mathrm{m}$ mesh test sieves to obtain the desired $\mathrm{C}_{3} \mathrm{~S}$ or $\mathrm{C}_{2} \mathrm{~S}$ powder.

$\mathrm{C}_{3} \mathrm{~A}$ was prepared by the Pechini method ${ }^{36)}$ using nitrate salts, $\mathrm{Ca}\left(\mathrm{NO}_{3}\right)_{2} \cdot 4 \mathrm{H}_{2} \mathrm{O}$ and $\mathrm{Al}\left(\mathrm{NO}_{3}\right)_{3} \cdot 9 \mathrm{H}_{2} \mathrm{O}$, as precursors. The aqueous solution of the precursors was prepared by dissolving them in $\sim 50 \mathrm{ml}$ of deionized water. Then, citric acid was added and the mixture was stirred to obtain a clear solution. Ethylene glycol was added to this solution, and the solution was continuously stirred at $80^{\circ} \mathrm{C}$, at which polyesterification reaction occurred along with the evaporation of excess water, which resulted in the formation of a viscous gel. The gel was dried at $150^{\circ} \mathrm{C}$ in a hot-air oven for $24 \mathrm{~h}$. The dried gel was heated at $400^{\circ} \mathrm{C}$ for $3 \mathrm{~h}$ and then ground to a powder form. A semi-dried slurry was prepared by moistening the dried powder with $15 \mathrm{wt} \%$ IPA and spherical balls of $\sim 1.5 \mathrm{~cm}$ diameter were formed. The dried spheres were sintered in air at different temperatures for $4 \mathrm{~h}$ and then quenched in liquid nitrogen. The clinker obtained after quenching was fully ground and sieved using $38 \mu \mathrm{m}$ mesh test sieves to obtain the desired $\mathrm{C}_{3} \mathrm{~A}$ powder.

\subsection{Synthesis of experimental Portland cements (EPC) from $C_{2} S, C_{3} S$, and $C_{3} A$}

EPCs with four different compositions were prepared by mixing pre-synthesized $\mathrm{C}_{2} \mathrm{~S}, \mathrm{C}_{3} \mathrm{~S}$, and $\mathrm{C}_{3} \mathrm{~A}$ with gypsum in 
Table 2. Four Compositions of EPCs were Prepared by Mixing Pre-Synthesized $\mathrm{C}_{2} \mathrm{~S}, \mathrm{C}_{3} \mathrm{~S}$ and $\mathrm{C}_{3} \mathrm{~A}$ with Gypsum in Different wt.\% Ratio

\begin{tabular}{cccccc}
\hline & \multicolumn{5}{c}{ wt.\% of various constituents } \\
\cline { 2 - 6 } & $\mathrm{C}_{2} \mathrm{~S}$ & $\mathrm{C}_{3} \mathrm{~S}$ & $\mathrm{C}_{3} \mathrm{~A}$ & Gypsum & Water \\
\hline EPC1 & 45 & 20 & 15 & - & 20 \\
$\mathrm{EPC} 2$ & 45 & 20 & 15 & 3 & 17 \\
$\mathrm{EPC} 3$ & 50 & 26 & 9 & - & 15 \\
$\mathrm{EPC} 4$ & 50 & 26 & 9 & 3 & 12 \\
\hline
\end{tabular}

different weight ratios, as given in Table 2.

\subsection{Structural characterization}

The phase compositions of $\mathrm{C}_{2} \mathrm{~S}, \mathrm{C}_{3} \mathrm{~S}, \mathrm{C}_{3} \mathrm{~A}$, and various $\mathrm{EPC}$ compositions in the powder form as well as during the hydration process were analyzed using a high-resolution Xray diffractometer (D/Max Ultima III, Rigaku, Japan) equipped with a $\mathrm{Cu}-\mathrm{K}_{\mathrm{\alpha}}$ radiation source $(1.5406 \AA)$ at a scan rate of $1 \% \mathrm{~min}$ in the scanning angle $(2 \theta)$ range of $10^{\circ}-80^{\circ}$. Phase identification was carried out by matching the experimental XRD data with the Inorganic Crystal Structure Database (ICSD) of Korea Institute of Science and Technology Information. The microstructures were analyzed using a field-emission scanning electron microscope (FE-SEM, S4700, Hitachi).

\subsection{Cytotoxicity test}

The cytotoxicity of the EPCs and ProRoot MTA was determined by performing an XTT assay. Human dental pulp cells (HPC) and human immortalized dental pulp cells (HIPC) were seeded at $1 \times 10^{4}$ cells per well on 96-well cultures for $24 \mathrm{~h}$ and treated with MTA (ProRoot MTA; Dentsply, Tulsa, OK) and the EPCs' extract solutions for 24 h. After $24 \mathrm{~h}$, the cell viability was analyzed using an EZCytox enhanced cell viability assay kit (Daeil Lab Service, Seoul, Korea). Briefly, $10 \mu \mathrm{l}$ of EZ-Cytox reagent was added to each well of the 96 -well plate and incubated at $37^{\circ} \mathrm{C}$ for 4 $\mathrm{h}$. The absorbance was measured at $420 \mathrm{~nm}$ using a spectrophotometer (VERSAmax multiplate reader; Molecular Devices, Sunnyvale, CA).

\subsection{Electrochemical measurements}

The electrochemical analysis of the hydration processes of $\mathrm{C}_{2} \mathrm{~S}, \mathrm{C}_{3} \mathrm{~S}, \mathrm{C}_{3} \mathrm{~A}$, and various EPCs was performed by EIS. The specimens for EIS were separately prepared in a specimen fixture $(16 \mathrm{~mm} \times 16 \mathrm{~mm} \times 10 \mathrm{~mm})$ made of an acrylic panel, as shown schematically in our previous work, ${ }^{29)}$ and EIS measurements were performed using a frequencyresponse analyzer (SI-1260, Solatron, England) following the same procedure mentioned therein. ${ }^{29)}$ The total handling time before the EIS measurement was $\sim 5 \mathrm{~min}$. The impedance spectra were collected as a function of frequency at 10 points per decade in a logarithmic manner between $10^{6}-0.1 \mathrm{~Hz}$ using Z60 software.
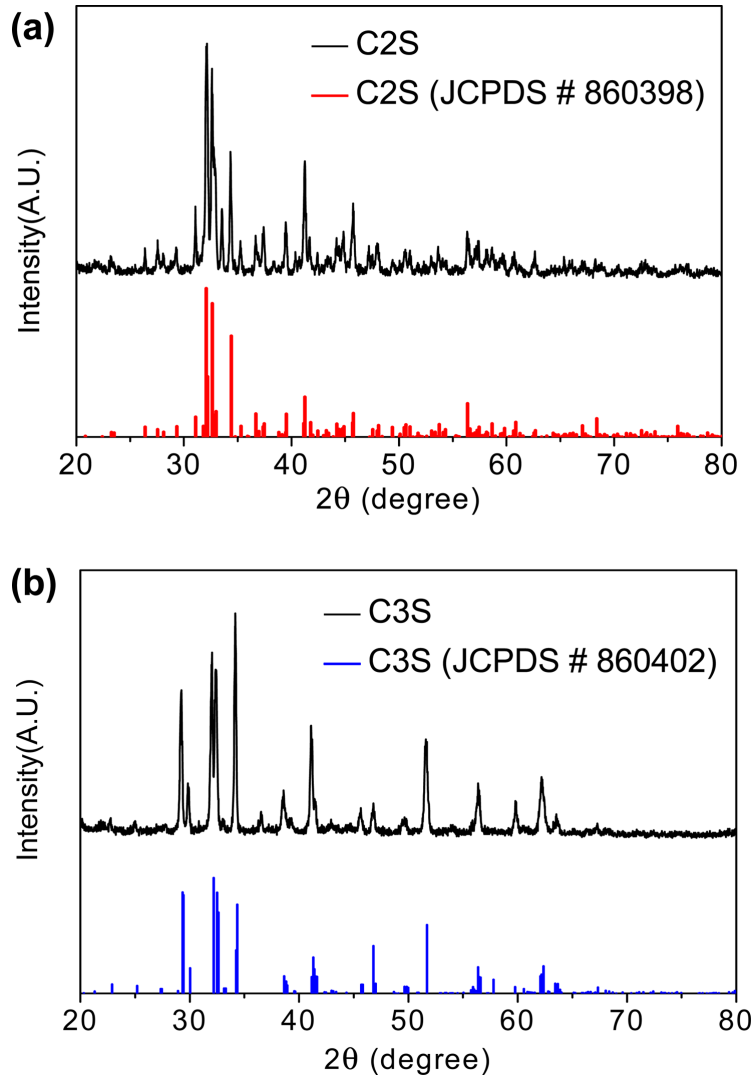

Fig. 2. XRD spectra of (a) $\mathrm{C}_{2} \mathrm{~S}$ and (b) $\mathrm{C}_{3} \mathrm{~S}$ powders synthesized by solid-state reaction.

\section{Results and Discussion}

Figure 2 shows the XRD spectra of the $\mathrm{C}_{2} \mathrm{~S}$ and $\mathrm{C}_{3} \mathrm{~S}$ powders synthesized by solid-state reactions. The diffraction peaks in the $\mathrm{C}_{2} \mathrm{~S}$ spectrum belong to $\beta-\mathrm{C}_{2} \mathrm{~S}$ (JCPDS \# 860398), whereas those in the $\mathrm{C}_{3} \mathrm{~S}$ spectrum belong to monoclinic $\mathrm{C}_{3} \mathrm{~S}$ (JCPDS \# 860402), which indicate that these powders have high purity. Fig. 3(a) shows the XRD spectra of $\mathrm{C}_{3} \mathrm{~A}$ synthesized by the Pechini method with sodium nitrite as one of the raw materials and quenched at different temperatures after sintering. Sodium nitrite was used to prepare $\mathrm{Na}^{+}$-substituted calcium aluminate. ${ }^{37)}$ In the XRD spectrum of the $1000^{\circ} \mathrm{C}$ quenched sample, many peaks corresponding to the $\mathrm{CaO}$ phase and cubic $\mathrm{C}_{3} \mathrm{~A}$ phase are prominently visible. The intensities of these peaks reduced upon quenching the sample at $1100^{\circ} \mathrm{C}$, and the $\mathrm{C}_{3} \mathrm{~A}$ sample mainly contains the orthorhombic $\mathrm{C}_{3} \mathrm{~A}$ phase. However, for the $1200^{\circ} \mathrm{C}$ quenched sample, diffraction peaks corresponding to the cubic $\mathrm{C}_{3} \mathrm{~A}$ phase again appeared. The lattice parameters of the $1100^{\circ} \mathrm{C}$ quenched sample calculated by Rietveld analysis considering the orthorhombic lattice (space group: Pbca) are $\mathrm{a}=10.782 \AA, \mathrm{b}=10.814 \AA$, and c $=15.040 \AA$. On the other hand, the XRD spectra of $\mathrm{C}_{3} \mathrm{~A}$ prepared by the Pechini method without using sodium nitrite as one of the raw materials and quenched at 1000 and $1100^{\circ} \mathrm{C}$ after sintering are shown in Fig. 3(c) and 3(d). Riet- 

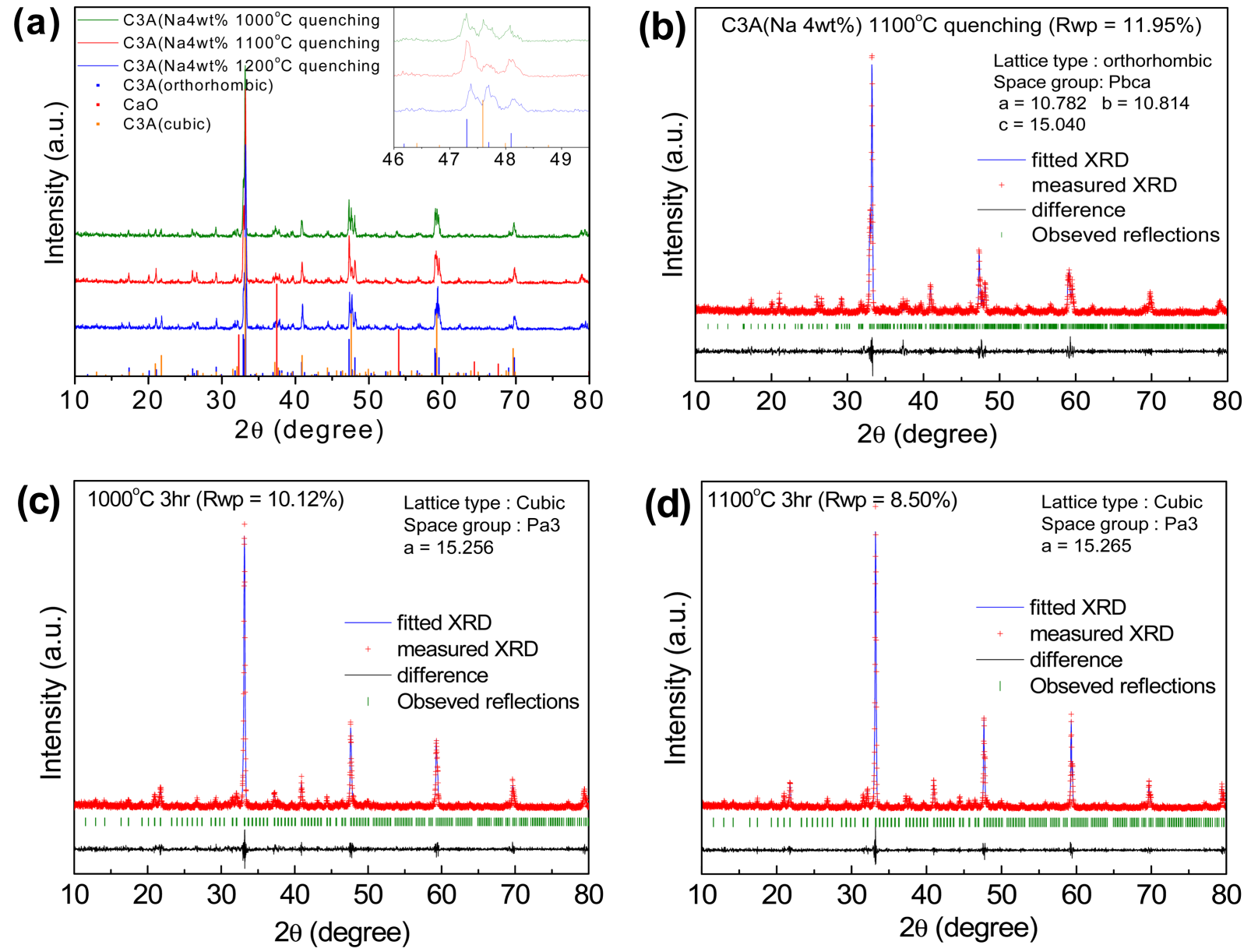

Fig. 3. (a) XRD spectra of $\mathrm{C}_{3} \mathrm{~A}$ synthesized by Pechini method with sodium nitrite as one of the raw materials and quenched at different temperatures after sintering; (b) Rietveld analysis of the $1100^{\circ} \mathrm{C}$ quenched sample shown in (a); (c, d) XRD spectra and Rietveld analysis of $\mathrm{C}_{3} \mathrm{~A}$ synthesized by Pechini method without sodium nitrite as one of the raw materials and quenched at (c) $1000^{\circ} \mathrm{C}$ and (d) $1100^{\circ} \mathrm{C}$.

veld analysis shows that these samples have a cubic lattice (space group: Pa3) with lattice parameters a $=15.256 \AA$ and $\mathrm{a}=15.265 \AA$, respectively. Although orthorhombic $\mathrm{C}_{3} \mathrm{~A}$ is more reactive than cubic $\mathrm{C}_{3} \mathrm{~A}^{38)}$ during the hydration process, only the sample rich in orthorhombic $\mathrm{C}_{3} \mathrm{~A}$ and quenched at $1100^{\circ} \mathrm{C}$ was used for the hydration studies.

The hydration process of the individual constituents, $\mathrm{C}_{3} \mathrm{~A}$, $\mathrm{C}_{2} \mathrm{~S}$, and $\mathrm{C}_{3} \mathrm{~S}$, was studied by EIS measurements. Impedance measurement allows the evaluation of the changes in ionic concentration of the pore solution as a result of microstructural development during the hydration process. The chemical reactions taking place during the hydration of the individual constituents, $\mathrm{C}_{3} \mathrm{~A}, \mathrm{C}_{2} \mathrm{~S}$, and $\mathrm{C}_{3} \mathrm{~S}$, can be represented as follows, ${ }^{39)}$ where $\mathrm{CH}$ represents calcium hydroxide $\left(\mathrm{Ca}(\mathrm{OH})_{2}\right)$ :

$$
\begin{aligned}
& 2 \mathrm{C}_{3} \mathrm{~A}+27 \mathrm{H}_{2} \mathrm{O} \rightarrow \mathrm{C}_{2} \mathrm{AH}_{19}+\mathrm{C}_{2} \mathrm{AH}_{8} \\
& 2 \mathrm{C}_{3} \mathrm{~S}+6 \mathrm{H}_{2} \mathrm{O} \rightarrow \mathrm{C}_{3} \mathrm{~S}_{2} \mathrm{H}_{3}+3 \mathrm{CH} \\
& 2 \mathrm{C}_{2} \mathrm{~S}+4 \mathrm{H}_{2} \mathrm{O} \rightarrow \mathrm{C}_{3} \mathrm{~S}_{2} \mathrm{H}_{3}+\mathrm{CH}
\end{aligned}
$$

Considering the low-frequency intercept of the semi-circu- lar part of the EIS data in the Nyquist plot during the hydration of $\mathrm{C}_{3} \mathrm{~A}^{40)}$ as a measure of the resistance of the $\mathrm{C}_{3} \mathrm{~A}$-water system, the resistances are plotted in Fig. 4(a). As can be seen, the resistance changes very rapidly in the initial $1-2 \mathrm{~h}$ and then gradually in the remaining period. It has been reported that $\mathrm{C}_{3} \mathrm{~A}$ reacts almost instantaneously with water and is accompanied by the release of a large amount of heat and the formation of metastable hydrated products such as $\left(\mathrm{Ca}_{2}\left[\mathrm{Al}(\mathrm{OH})_{5}\right]_{2} \cdot 3 \mathrm{H}_{2} \mathrm{O}, 2\left[\mathrm{CaAl}(\mathrm{OH})_{7} \cdot 3 \mathrm{H}_{2} \mathrm{O}\right.\right.$, and $4 \mathrm{CaO} \cdot \mathrm{Al}_{2} \mathrm{O}_{3} \cdot 19 \mathrm{H}_{2} \mathrm{O} .{ }^{41)} \mathrm{In}$ the present study, $\mathrm{C}_{3} \mathrm{~A}$ shows a similar behavior.

Previously, the hydration of $\mathrm{C}_{3} \mathrm{~S}$ and $\mathrm{C}_{2} \mathrm{~S}$ has been studied by different analytical techniques. ${ }^{42-47)}$ In the clinker composition, although the amount of $\mathrm{C}_{3} \mathrm{~A}$ is $5-10 \mathrm{wt} \%$, it has a strong influence on the setting and hardening times of cement because of its high reactivity with water. ${ }^{39,48)}$ The values of resistances calculated from the variations in the impedance spectra during the hydration of $\mathrm{C}_{3} \mathrm{~S}$ are plotted in Fig. 4(b). As can be seen, initially, the resistance decreases very rapidly in the initial 10-15 $\mathrm{min}$ and then gradually for the next $2 \mathrm{~h}$ due to the hydrolysis of $\mathrm{C}_{3} \mathrm{~S}$ and 
July 2019 Investigation on Hydration Process and Biocompatibility of Calcium Silicate-Based Experimental Portland Cements
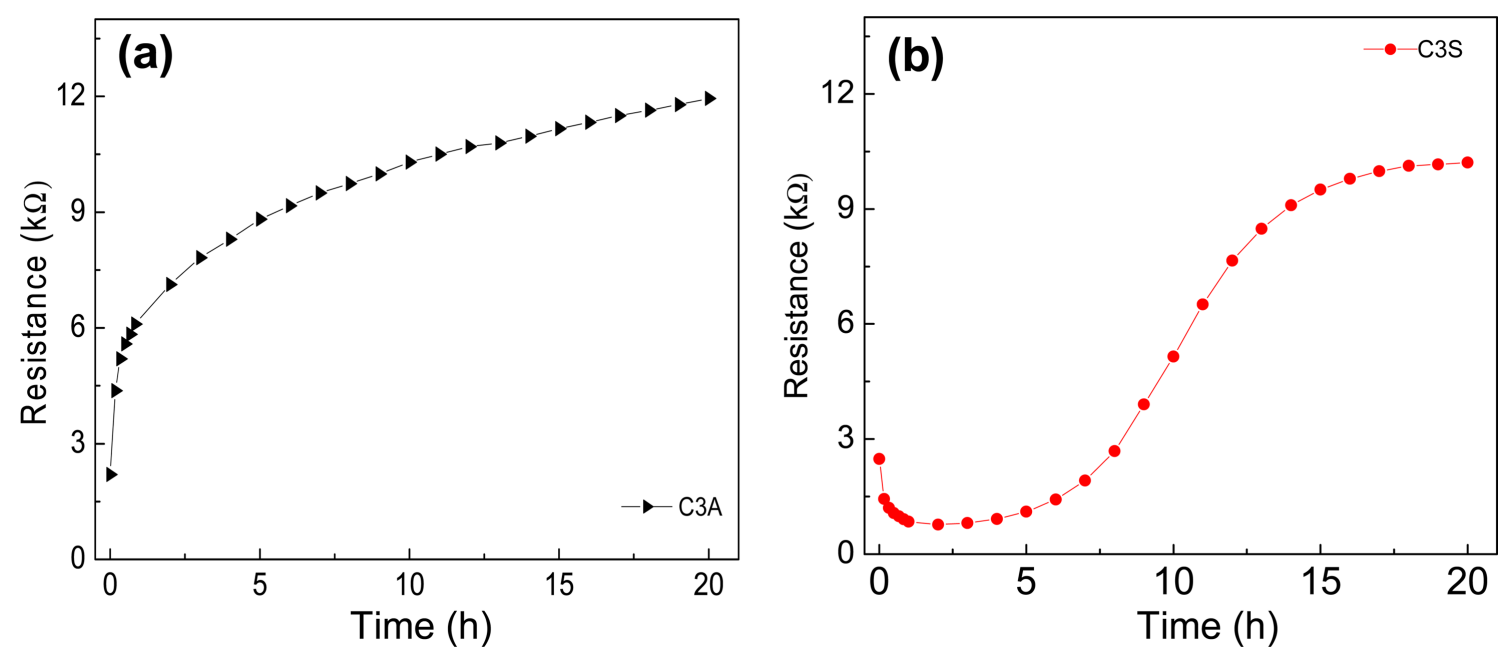

Fig. 4. Variations in resistances of (a) $\mathrm{C}_{3} \mathrm{~A}$ system and (b) $\mathrm{C}_{3} \mathrm{~S}$ system during the hydration process.

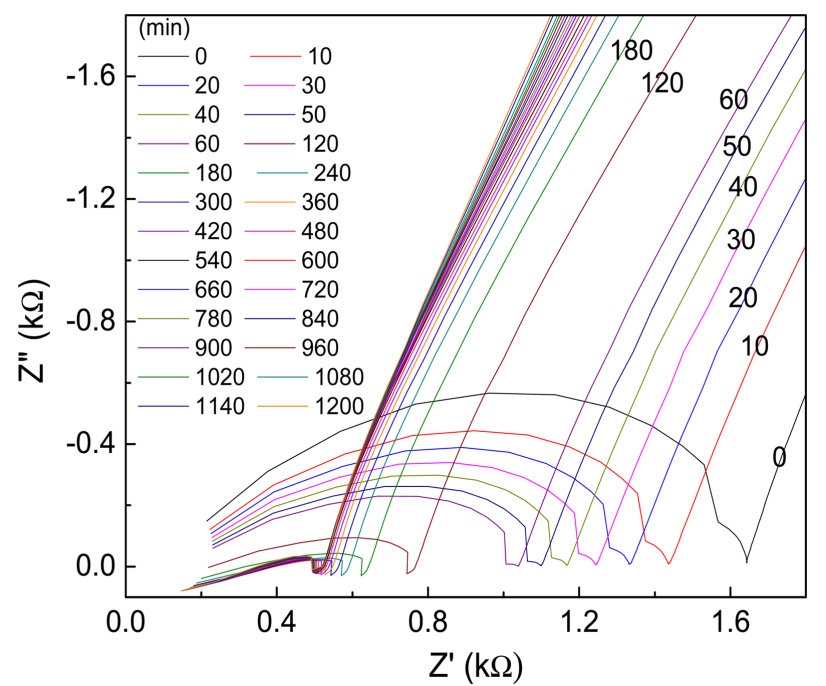

Fig. 5. Z' vs. Z" plot derived from EIS measurements during the hydration of $\mathrm{C}_{2} \mathrm{~S}$.

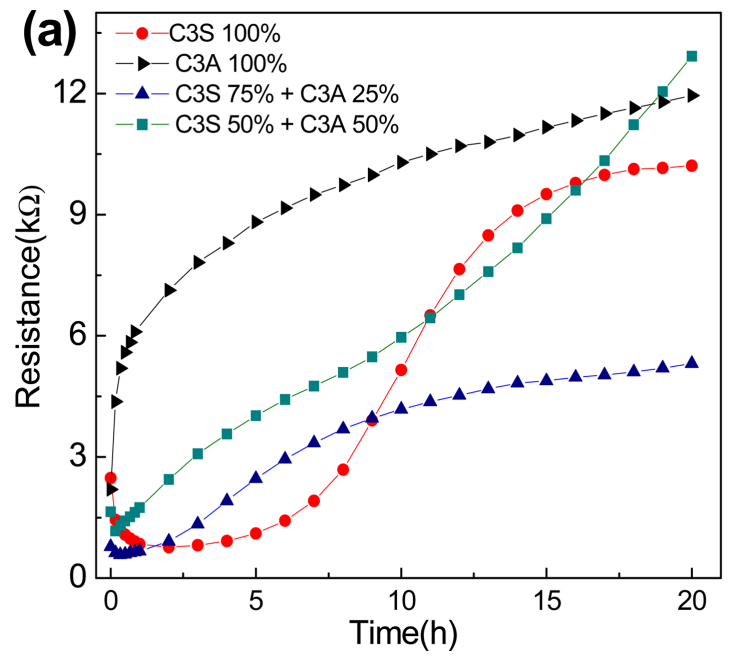

the resultant release of calcium ions and hydroxide ion from the surface of the $\mathrm{C}_{3} \mathrm{~S}$ grains. ${ }^{39)}$ Once the dormant phase sets in and the concrete is in a plastic state, the resistance remains nearly unchanged for about the next $2 \mathrm{~h}$. When the setting of concrete starts, the resistance increases again, first gradually and then rapidly. As early hardening begins, calcium and hydroxide ions start crystallizing, and hydration products are continuously formed. The hydration products form a thick coating around the anhydrous $\mathrm{C}_{3} \mathrm{~S}$ grains and force the water to diffuse through the coating to react with the unreacted $\mathrm{C}_{3} \mathrm{~S}$ grains. ${ }^{49)}$ Under this diffusion-controlled phase, the resistance increases steadily. Fig. 5 shows the variations in the Nyquist plot during the hydration of $\mathrm{C}_{2} \mathrm{~S}$. It has been reported that the hydration of $\mathrm{C}_{2} \mathrm{~S}$ is much slower than $\mathrm{C}_{3} \mathrm{~S}$ hydration, and as a result, the resistance decreases very slowly during the hydration of $\mathrm{C}_{2} \mathrm{~S}$. This is because of its lower reactivity compared with $\mathrm{C}_{3} \mathrm{~S}$, that is, although the same calcium and hydroxide ions are released, albeit in lesser in numbers, they did not cause a rapid

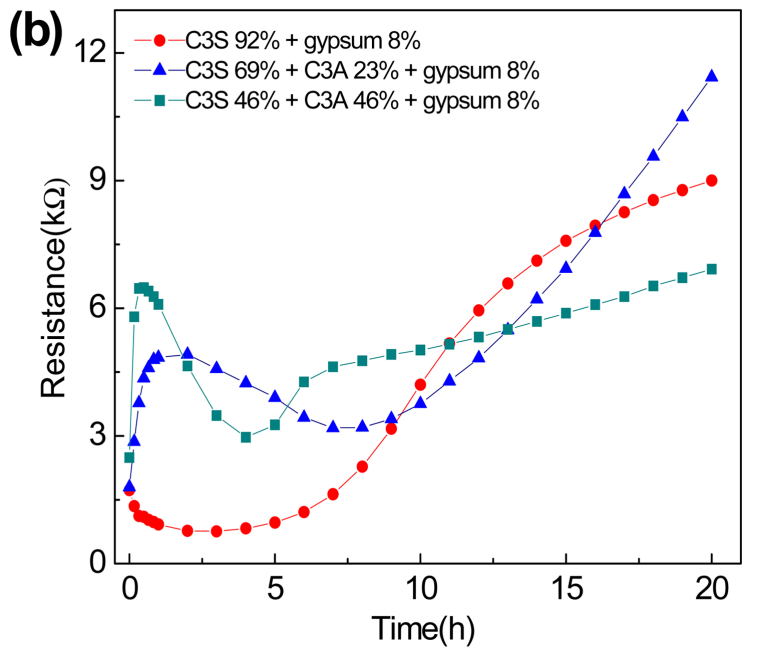

Fig. 6. Variation in resistances of various compositions during the hydration process: (a) in the absence of gypsum and (b) in the presence of gypsum. 
decrease in resistance during the hydration of $\mathrm{C}_{2} \mathrm{~S}$. Due to its slower rate of hydration, $\mathrm{C}_{2} \mathrm{~S}$ does not contribute to initial strength, and therefore, in the present work, we did not study the effect of $\mathrm{C}_{2} \mathrm{~S}$ on the initial hydration of our experimental cement.

$\mathrm{C}_{3} \mathrm{~A}$ undergoes fast hydration, and the addition of gypsum (calcium sulfate) has been reported to slow down the hydration reaction. ${ }^{38)}$ In Portland cement, it is generally accepted that the effect of the addition of gypsum is mainly associated with its intensive reaction with the $\mathrm{C}_{3} \mathrm{~A}$ phase. However, many studies have shown the indirect effect of gypsum on the hydration of silicate phases, with its addition resulting in the acceleration of $\mathrm{C}_{3} \mathrm{~S}$ hydration and improvement in the strength of the $\mathrm{C}_{3} \mathrm{~S}$ paste by entering $\mathrm{C}-\mathrm{S}-\mathrm{H}$ in some way. ${ }^{50-52)}$ Therefore, we subsequently studied the hydration behaviors of $\mathrm{C}_{3} \mathrm{~A}$ and $\mathrm{C}_{3} \mathrm{~S}$ mixtures in the absence (50:50 and $25: 75 \mathrm{wt} \%$ of $\mathrm{C}_{3} \mathrm{~A}$ and $\mathrm{C}_{3} \mathrm{~S}$ ) and presence (46:46 and $23: 69 \mathrm{wt} \%$ of $\mathrm{C}_{3} \mathrm{~A}$ and $\mathrm{C}_{3} \mathrm{~S}$, and additional $8 \mathrm{wt} \%$ gypsum) of gypsum by EIS. The variations in resistance during the hydration of these mixtures are plotted in Fig. 6. In the absence of gypsum (Fig. 6(a)), the change in resistance of the $\mathrm{C}_{3} \mathrm{~A}+\mathrm{C}_{3} \mathrm{~S}$ mixture follows an intermediate trend with a rapid initial decrease and a subsequent gradual increase in the resistance of the mixture. However, in the presence of gypsum (Fig. 6(b)), the change in the resistance of the $\mathrm{C}_{3} \mathrm{~A}+\mathrm{C}_{3} \mathrm{~S}$ mixture is initially dominated by the change in the resistance of $\mathrm{C}_{3} \mathrm{~A}$, which is followed by a behavior intermediate to those of the two components. The change in the setting behavior of the mixture after $\sim 10 \mathrm{~h}$ in the presence of gypsum is shown in Fig. 7; for the mixture having equal amounts of $\mathrm{C}_{3} \mathrm{~S}$ and $\mathrm{C}_{3} \mathrm{~A}$, the resistance increases at a much slower rate during the subsequent setting process (Fig. $7(\mathrm{a})$ ), while for the mixture having a higher amount of $\mathrm{C}_{3} \mathrm{~S}$, the resistance increases at a much faster rate during the subsequent setting process (Fig. 7(b)). This could be because with a lower $\mathrm{C}_{3} \mathrm{~A}: \mathrm{C}_{3} \mathrm{~S}$ ratio, the amount of gypsum becomes higher than that required to suppress the hydration of $\mathrm{C}_{3} \mathrm{~A}$; therefore, the presence of a high amount of gypsum accelerates the setting of cement by generating a clotting agent. ${ }^{53)}$

Furthermore, experimental dental cements with four dif-
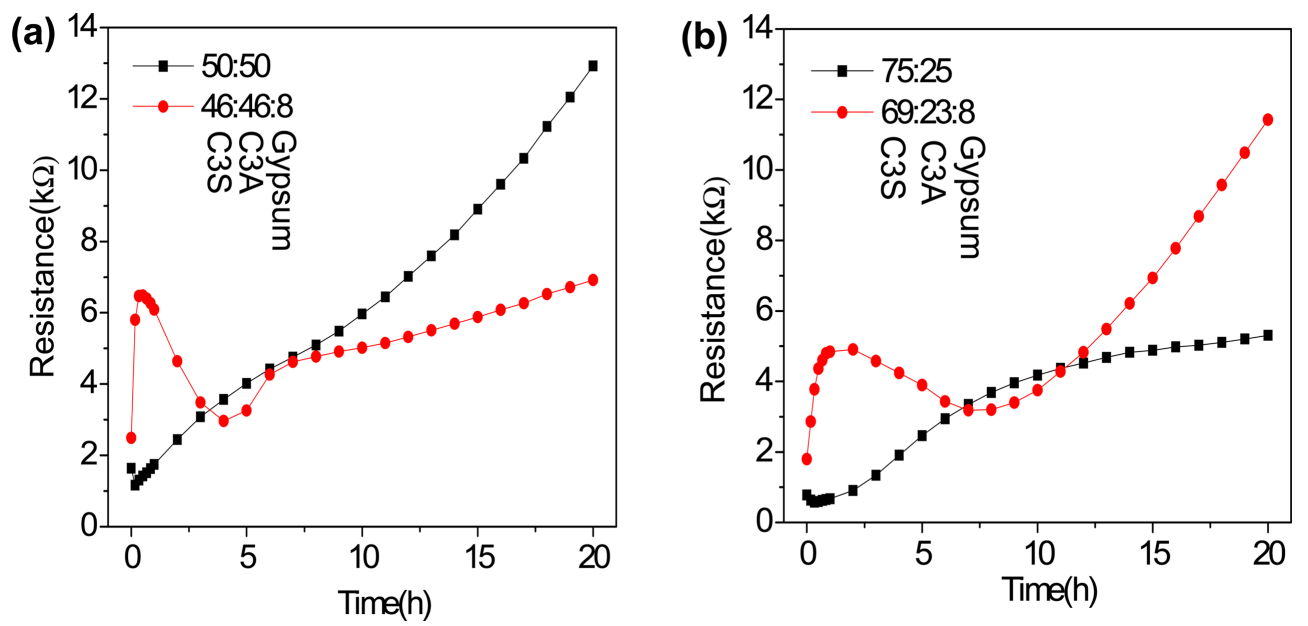

Fig. 7. Variation in resistances of various compositions during the hydration process: with $\mathrm{C}_{3} \mathrm{~S}: \mathrm{C}_{3} \mathrm{~A}$ ratios of (a) $1: 1$ wt\% and (b) $3: 1 \mathrm{wt} \%$
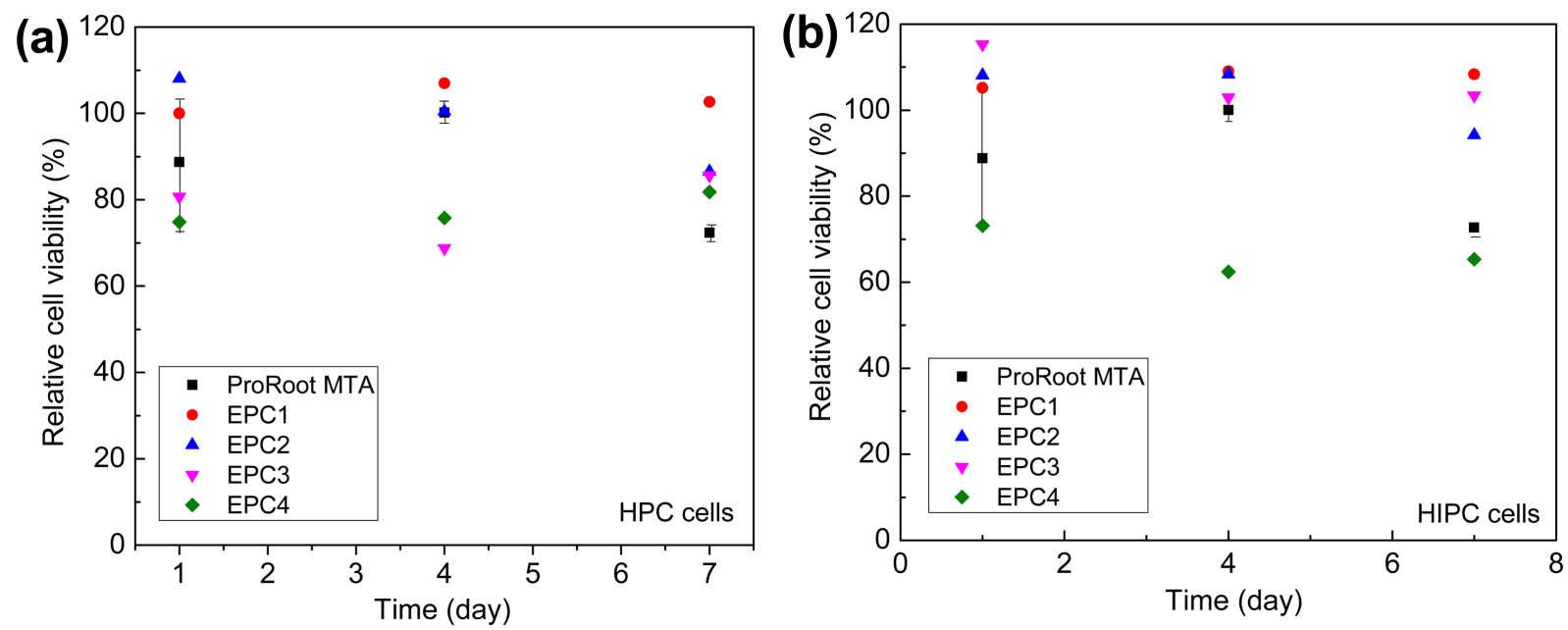

Fig. 8. Cytotoxicity of various EPC compositions to (a) HPC cells and (b) HIPC cells. 

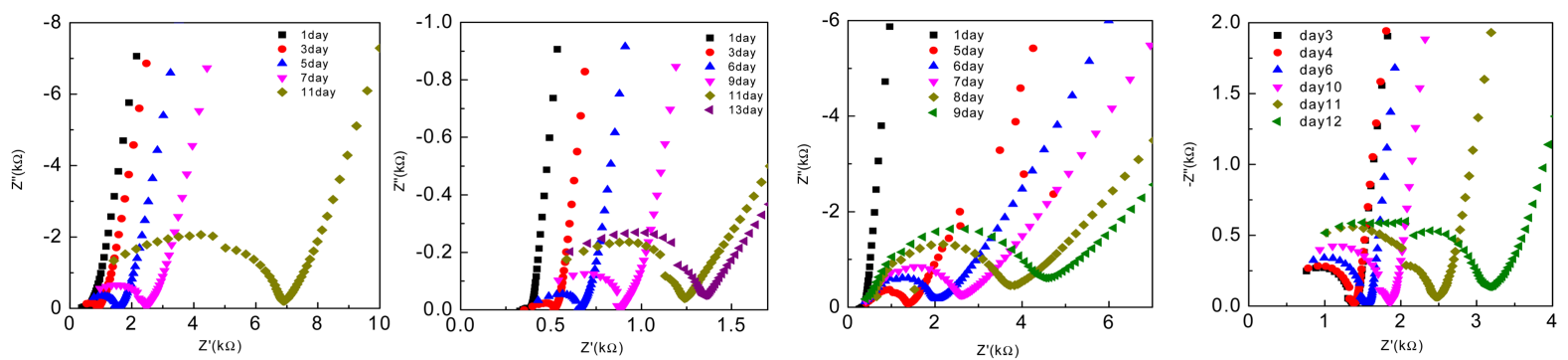

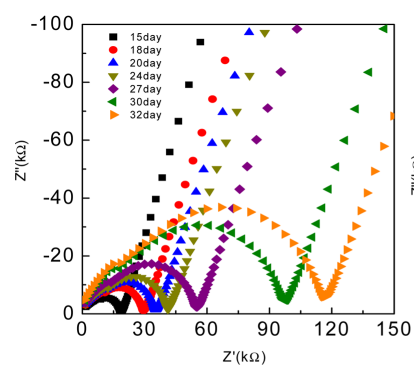

(a)

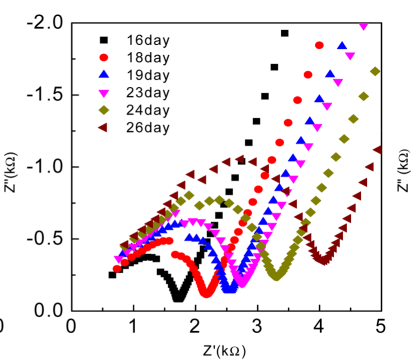

(b)

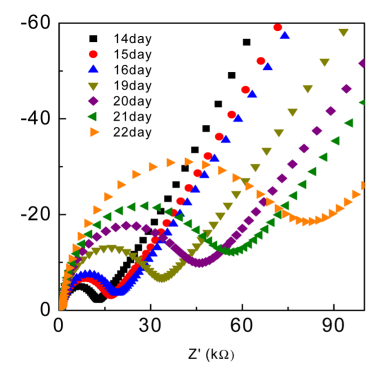

(c)

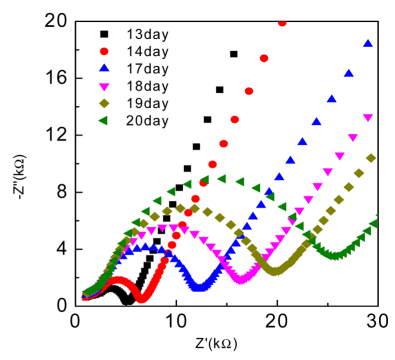

(d)

Fig. 9. Variation in EIS spectra of hydration processes of (a) EPC1, (b) EPC2, (c) EPC3, and (d) EPC4.

ferent compositions (as mentioned in Table 2) were prepared using the lab-synthesized $\mathrm{C}_{3} \mathrm{~A}, \mathrm{C}_{3} \mathrm{~S}$, and $\mathrm{C}_{2} \mathrm{~S}$. However, since restorative materials contact or interact with body tissues and fluids, the biological compatibility of materials must be taken into account during material selection. Fig. 8 shows the cell viability of HPC and HIPC cells with cultured on the test materials. As can be seen, the cells cultured for $24 \mathrm{~h}$ on EPCs were viable and proliferated in direct contact with the cement surfaces. In addition, the EPCs and ProRoot MTA did not exhibit any significant cytotoxicity to HPC and HIPC cells for 7 days. Moreover, there is no significant difference in the cell viabilities of ProRoot MTA and the experimentally manufactured cements, which indicated that all the EPCs are sufficiently biocompatible with human dental pulp cells.

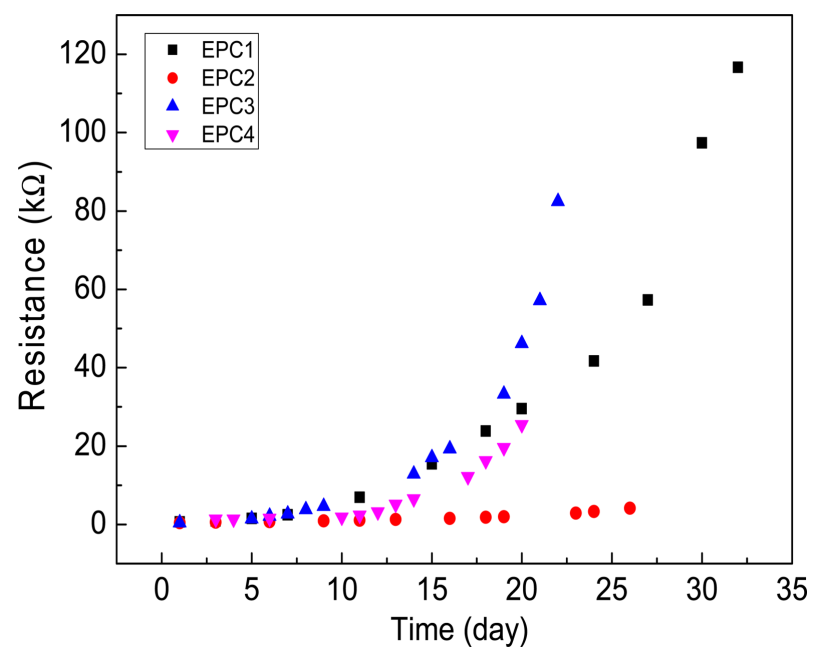

Fig. 10. Variation in resistances of various EPC compositions during the hydration process.
Finally, we studied the hydration process of the different EPCs by EIS and the changes in the Z' vs. Z" plots of the various EPCs are plotted in Fig. 9. During the setting of cement-based materials, the overall combination of solid network structure and composition of the ion-conducting liquid phase determines the electrical conductivity of the system. ${ }^{29)}$ In addition, the continuously increasing solid phase penetrates the liquid phase due to the formation of silicate and hydrate products during the setting process, thus decreasing the porous ion-conducting pathways, which results in a continuous increase in the system's resistance; this is indicated by the increase in the size of the high-frequency semicircles of the CPCs with setting time (Fig. 9). The changes in resistances during the hydration of the EPC compositions are plotted in Fig. 10. As can be seen, without gypsum (i.e., for EPC1 and EPC3), the resistance of EPC3 increases at a faster rate and reaches $>80 \Omega$ in 22 days; however, during the same period, the resistance of EPC1 is $<40 \Omega$. On the other hand, for EPC2 and EPC4, the resistance increases at a much slower rate compared with EPC1 and EPC3, which indicates that the addition of gypsum retards the hydration process of EPCs. Among the EPCs with gypsum (i.e., EPC2 and EPC4), the resistance of EPC2 increases at a slower rate and is nearly one order of magnitude lower than that of EPC4 in 20 days.

\section{Conclusions}

In this work, three major clinker constituents of Portland cement- $\mathrm{C}_{3} \mathrm{~S}, \mathrm{C}_{2} \mathrm{~S}$, and $\mathrm{C}_{3} \mathrm{~A}$-were synthesized in the laboratory and their phase compositions were characterized by XRD analysis. $\mathrm{C}_{3} \mathrm{~A}$ was synthesized by the Pechini method, whereas $\mathrm{C}_{3} \mathrm{~S}$ and $\mathrm{C}_{2} \mathrm{~S}$ were synthesized by solid-state reactions. The hydration process of the individual constituents 
and their combinations was investigated by EIS and the effect of the addition of gypsum on their hydration processes was examined. It was observed that the setting behavior of the mixture varied after $\sim 10 \mathrm{~h}$ in the presence of gypsum; for the mixture having equal amounts of $\mathrm{C}_{3} \mathrm{~S}$ and $\mathrm{C}_{3} \mathrm{~A}$, the resistance increased at a much slower rate during the subsequent setting process, whereas for the mixture with a higher amount of $\mathrm{C}_{3} \mathrm{~S}$, the resistance increased at a much faster rate during the subsequent setting process. This could be because with a lower $\mathrm{C}_{3} \mathrm{~A}: \mathrm{C}_{3} \mathrm{~S}$ ratio, the amount of gypsum becomes higher than that required to suppress the hydration of $\mathrm{C}_{3} \mathrm{~A}$; therefore, the presence of a high amount of gypsum accelerates the setting of cement. Four different EPCs were prepared using the lab-synthesized $\mathrm{C}_{3} \mathrm{~A}, \mathrm{C}_{3} \mathrm{~S}$, and $\mathrm{C}_{2} \mathrm{~S}$, and their hydration processes were examined by EIS. In the XTT assay, the EPCs did not exhibit any significant cytotoxicity to HPC and HIPC cells for 7 days, and all the EPCs showed biocompatibility equivalent to that of the commercial cement, ProRoot MTA. This indicates that all the EPCs are potential substitutes for commercial dental cement.

\section{REFERENCES}

1. M. Rinastiti, "Biomaterials in Dentistry," pp. 183-205 in Biomaterials and Medical Devices, Eds. by F. Mahyudin and H. Hermawan, Springer International Publishing Switzerland 2016.

2. N. Ewoldsen and R. S. Demke, "A Review of Orthodontic Cements and Adhesives," Am. J. Orthod. Dentofacial Orthop., 120 [1] 45-8 (2001).

3. J. Paul, "Dental Cements- A Review to Proper Selection," Int. J. Curr. Microbiol. App. Sci., 4 [2] 659-69 (2015).

4. W. L. Kydd, J. I. Nicholls, G. Harrington, and M. Freeman, "Marginal Leakage of Cast Gold Crowns Luted with Zinc Phosphate Cement: An in vivo Study," J. Prosthet. Dent., 75 [1] 9-13 (1996).

5. T. F. Watson, A. R. Atmeh, S. Sajini, R. J. Cook, and F. Festy, "Present and Future of Glass-Ionomers and CalciumSilicate Cements as Bioactive Materials in Dentistry: Biophotonics-based Interfacial Analyses in Health and Disease," Dent. Mater., 30 [1] 50-61 (2014).

6. L. Grech, B. Mallia, and J. Camilleri, "Investigation of the Physical Properties of Tricalcium Silicate Cement-based Root-End Filling Materials," Dent. Mater., 29 [2] e20-8 (2013).

7. M. S. Baig and G. J. P. Fleming, "Conventional GlassIonomer Materials: A Review of the Developments in Glass Powder, Polyacid Liquid and the Strategies of Reinforcement," J. Dent., 43 [8] 897-912 (2015).

8. J. M. Meyer, M. A. Cattani-Lorente, and V. Dupuis, "Compomers: Between Glass-Ionomer Cements and Composites," Biomaterials, 19 [6] 529-39 (1998).

9. I. Radovic, F. Monticelli, C. Goracci, Z. R. Vulicevic, and M. Ferrari, "Self-Adhesive Resin Cements: A Literature Review," J. Adhes. Dent., 10 [4] 251-58 (2008).

10. T. Komabayashi, Q. Zhu, R. Eberhart, and Y. Imai, "Current Status of Direct Pulp-Capping Materials for
Permanent Teeth,” Dent. Mater. J., 35 [1] 1-12 (2016).

11. M. Karapinar-Kazandag, B. Basrani, V. T.-K. Yamagishi, A. Azarpazhooh, and S. "Friedman, Fracture Resistance of Simulated Immature Tooth Roots Reinforced with MTA or Restorative Materials," Dent. Traumatol., 32 [2] 14652 (2016).

12. J. Camilleri, Mineral Trioxide Aggregate in Dentistry: From preparation to Application; Springer-Verlag Berlin Heidelberg, 2014.

13. M. Torabinejad and D. J. White, "Tooth Filling Material and Method of Use"; U.S. Patent 5411547, 1993.

14. H. W. Roberts, J. M. Toth, D. W. Berzins, and D. G. Charlton, "Mineral Trioxide Aggregate Material Use in Endodontic Treatment: A Review of the Literature," Dent. Mater., 24 [2] 149-64 (2008).

15. M. Parirokh and M. Torabinejad, "Mineral Trioxide Aggregate: A Comprehensive Literature Review-Part I: Chemical, Physical, and Antibacterial Properties," J. Endod., 36 [1] 16-27 (2010).

16. Ö. Malkondu, M. K. Kazandag, and E. Kazazoglu, "A review on Biodentine, a Contemporary Dentine Replacement and Repair Material," BioMed Res. Int., 2014160951 (2014).

17. T. F. Watson, A. R. Atmeh, S. Sajini, R. J. Cook, and F. Festy, "Present and Future of Glass-Ionomers and CalciumSilicate Cements as Bioactive Materials in Dentistry: Biophotonics-based Interfacial Analyses in Health and Desease," Dent. Mater., 30 [1] 50-61 (2014).

18. M. Parirokh and M. Torabinejad, "Calcium Silicate-based Cements," pp. 281-332 in Mineral Trioxide Aggregate: Properties and Clinical Applications, Ed. by M. Torabinejad, John Wiley \& Sons, Inc., Hoboken, USA, 2014.

19. C. M. Bramante, A. C. C. O. Demarchi, I. G. de Moraes. N. Bernadineli, R. B. Garcia, L. S. W. Spangberg, and M. A. H. Duarte, "Presence of Arsenic in Different Types of MTA and White and Gray Portland Cement," Oral Surg. Oral Med. Oral Pathol. Oral Radiol. Endod., 106 [6] 90913 (2008).

20. C. M. Primus, "Comments on Testing for the Presence of Arsenic in MTA and Portland Cement," Oral Surg. Oral Med. Oral Pathol. Oral Radiol. Endod., 108 [6] 479-80 (2009).

21. G. De-Deus, M. C. B. de Souza, R. A. S. Fidel, S. R. Fidel, R. C. de Campos, and A. S. Luna, "Negligible Expression of Arsenic in Some Commercially Available Brands of Portland Cement and Mineral Trioxide Aggregate," J. Endod., 35 [6] 887-90 (2009).

22. M. A. Marciano, M. A. H. Duarte, and J. Camilleri, "Calcium Silicate-based Sealers: Assessment of Physicochemical Properties, Porosity and Hydration," Dent. Mater., 32 [2] e30-40 (2016).

23. A. D. Santos, E. B. Araújo, K. Yukimitu, J. C. Barbosa, and J. C. S. Moraes, "Setting Time and Thermal Expansion of Two Endodontic Cements," Oral Surg. Oral Med. Oral Pathol. Oral Radiol. Endod., 106 [3] 77-9 (2008).

24. B. Hemasathya, C. M. B. Mony, and V. Prakash, "Recent Advances in Root End Filling Materials: A Review," Biomed. Pharmacol. J., 8 219-24 (2015).

25. S. Asgary, S. Shahabi, T. Jafarzadeh, S. Amini, and S. 
July 2019 Investigation on Hydration Process and Biocompatibility of Calcium Silicate-Based Experimental Portland Cements

Kheirieh, "The Properties of a New Endodontic Material," J. Endod., 34 [8] 990-93 (2008).

26. S. W. Chang, W. J. Bae, J. K. Yi, S. Lee, D. W. Lee, K. Y. Kum, and E. C. Kim, "Odontoblastic Differentiation, Inflammatory Response, and Angiogenic Potential of 4 Calcium Silicate-based Cements: Micromega MTA, ProRoot MTA, RetroMTA, and Experimental Calcium Silicate Cement," J. Endod., 41 [9] 1524-29 (2015).

27. M. H. Huang, Y. F. Shen, T. T. Hsu, T. H. Huang, and M. Y. Shie, "Physical Characteristics, Antimicrobial and Odontogenesis Potentials of Calcium Silicate Cement Containing Hinokitiol," Mater. Sci. Eng., C, 65 1-8 (2016).

28. Y. C. Hwang, D. H. Kim, I. N. Hwang, S. J. Song, Y. J. Park, J. T. Koh, H. H. Son, and W. M. Oh, "Chemical Constitution, Physical Properties, and Biocompatibility of Experimentally Manufactured Portland Cement," $J$. Endod., 37 [1] 58-62 (2011).

29. K. P. Seong, S. Y. Jeon, B. Singh, J. H. Hwang, and S. J. Song, "Comparative Study of an Experimental Portland Cement and ProRoot MTA by Electrochemical Impedance Spectroscopy," Ceram. Int., 40 [1] 1741-46 (2014).

30. H. M. Setbon, J. Devaux, A. Iserentant, G. Leloup, and J. G. Lepince, "Influence of Composition on Setting Kinetics of New Injectable and/or Fast Setting Tricalcium Silicate Cements," Dent. Mater., 30 [12] 1291-303 (2014).

31. P. Gu, P. Xie, J. J. Beaudoin, and R. Brousseau, "A.C. Impedance Spectroscopy (I): A New Equivalent Circuit Model for Hydrated Portland Cement Paste," Cem. Concr. Res., 22 [5] 833-40 (1992).

32. P. Xie, P. Gu, Z. Xu, and J. J. Beaudoin, "A Rationalized A.C. Impedance Model for Microstructural Characterization of Hydrating Cement Systems," Cem. Concr. Res., 23 [2] 359-67 (1993).

33. C. Villat, V. X. Tran, N. Pradelle-Plasse, P. Ponthiaux, F. Wenger, B. Grosgogeat, and P. Colon, "Impedance Methodology: A New Way to Characterize the Setting Reaction of Dental Cements," Dent. Mater., 26 [12] 112732 (2010).

34. A. Mogus-Milankovic, K. Sklepic, M. Calogovic, M. Marcius, K. Prskalo, B. Jankovic, and Z. Tarle, "Impedance as a Measure of Setting Reaction in Glass Ionomer Cements," J. Non-Cryst. Solids, 389 93-103 (2014).

35. A. Santic, M. Calogovic, L. Pavic, J. Gladic, Z. Vucic, D. Lovric, K. Prskalo, B. Jankovic, Z. Tarle, and A. MogusMilankovic, "New Insights into the Setting Processes of Glass Ionomer Cements from Analysis of Dielectric Properties,” J. Am. Ceram. Soc., 98 [12] 3869-76 (2015).

36. A. Gaki, R. Chrysafi, and G. Kakali, "Chemical Synthesis of Hydraulic Calcium Aluminate Compounds Using the Pechini Technique," J. Eur. Ceram. Soc., 27 [2-3] 178184 (2007).

37. A. N. Christensen, N. V. Y. Scarlett, I. C. Madsen, T. R. Jensen, and J. C. Hanson, "Real Time Study of Cement and Clinker Phases Hydration," Dalton Trans., 2003 [8] 1529-36 (2003).

38. A. P. Kirchheim, V. Fernàndez-Altable, P. J. M. Monteiro, D. C. C. D. Molin, and I. Casanova, "Analysis of Cubic and
Orthorhombic $\mathrm{C}_{3} \mathrm{~A}$ Hydration in Presence of Gypsum and Lime," J. Mater. Sci., 44 [8] 2038-45 (2009).

39. I. Sharpley, The Effect of Hydration on the Microstructural Properties of Individual Phases of Ordinary Portland Cement; Master Dissertation, University of London, 2015.

40. R. T. Coverdale, B. J. Christensen, H. M. Jennings, T. O. Mason, D. P. Bentz, and E. J. Garboczi, "Interpretation of Impedance Spectroscopy of Cement Paste via Computer Modeling," J. Mater. Sci., 30 [3] 712-19 (1995).

41. E. Breval, "C ${ }_{3} \mathrm{~A}$ Hydration," Cem. Concr. Res., 6 [1] 12937 (1976).

42. E. Pustovgar, R. P. Sangodkar, A. S. Andreev, M. Palacios, B. F. Chmelka, R. J. Flatt, and J. B. d'Espinose de Lacaillerie, "Understanding Silicate Hydration from Quantitative Analyses of Hydrating Tricalcium Silicates," Nat. Commun., 710952 (2016).

43. S. Goni, F. Puertas, M. S. Hernandez, M. Palacios, A. Guerrero, J. S. Dolado, B. Zanga, and F. Baroni, "Quantitative Study of Hydration of $\mathrm{C}_{3} \mathrm{~S}$ and $\mathrm{C}_{2} \mathrm{~S}$ by Thermal Analysis, Evolution and Composition of C-S-H Gels Formed," J. Therm. Anal. Calorim., 102 [3] 965-73 (2010).

44. N. L. Thomas and D. D. Double, "The Hydration of Portland Cement, $\mathrm{C}_{3} \mathrm{~S}$ and $\mathrm{C}_{2} \mathrm{~S}$ in the Presence of a Calcium Complexing Admixture (EDTA)," Cem. Concr. Res., 13 [3] 391-400 (1983).

45. L. Valentini, M. C. Dalconi, M. Favero, G. Artioli, and G. Ferrari, "In-Situ XRD Measurement and Quantitative Analysis of Hydrating Cement: Implications for Sulfate Incorporation in C-S-H,” J. Am. Ceram. Soc., 98 [4] 1259-64 (2015).

46. G. Kakali, S. Tsivilis, E. Aggeli, and M. Bati, "Hydration Products of $\mathrm{C}_{3} \mathrm{~A}, \mathrm{C}_{3} \mathrm{~S}$ and Portland Cement in the Presence of $\mathrm{CaCO}_{3}$," Cem. Concr. Res., 30 [7] 1073-77 (2000).

47. J. W. Bullard, H. M. Jennings, R. A. Livingston, A. Nonat, G. W. Scherer, J. S. Schweitzer, K. L. Scrivener, and J. J. Thomas, "Mechanisms of Cement Hydration," Cem. Concr. Res., 41 [12] 1208-23 (2011).

48. H. F. W. Taylor, Cement Chemistry; Ch. 1, 2nd Ed., Thomas Telford, London, 1997.

49. S. Garrault and A. Nonat, "Hydrated Layer Formation on Tricalcium and Dicalcium Silicate Surfaces: Experimental Study and Numerical Simulations," Langmuir, 17 [26] 8131-38 (2001).

50. A. Bentur, "Effect of Gypsum on the Hydration and Strength of $\mathrm{C}_{3} \mathrm{~S}$ Pastes," J. Am. Ceram. Soc., 59 [5-6] 210-13 (1976).

51. P.-C. Aitcin, Portland Cement Hydration, pp. 146-205 in Binders for Durable and Sustainable Concrete, CRC Press, New York, 2007.

52. Y. Zhang and X. Zhang, "Research on Effect of Limestone and Gypsum on $\mathrm{C}_{3} \mathrm{~A}, \mathrm{C}_{3} \mathrm{~S}$ and PC Clinker System," Constr. Building Mater., 22 [8] 1634-42 (2008).

53 M. Y. Hassaan, "Effect of Gypsum on the Strength Development of Portland Cement by Mössbauer Spectrometry," Hyperfine Interact., 42 [1-4] 1199-202 (1988). 